\title{
A HEMOLYTIC MODIFICATION OF THE HEMAGGLUTINATION TEST FOR ANTIBODIES AGAINST TUBERCLE BACILLUS ANTIGENS
}

\author{
BY GARDNER MIDDLEBROOK
}

\author{
(From the Laboratories of The Rockefeller Institute for Medical Research, New York City)
}

(Submitted for publication June 20, 1950; accepted, August 7, 1950)

A specific hemagglutination reaction has been described (1) between the sera of tuberculous experimental animals or human beings and sheep erythrocytes treated with extracts or products of the culture filtrates of tubercle bacilli. Observations on this reaction have been confirmed and extended by other investigators $(2-6)$. The present paper is concerned with a modification of this test which involves the addition of complement to the reaction system and thereby often transforms the reaction from one of hemagglutination to one of hemolysis. This hemolytic phenomenon was first observed while investigating the possibility of using tuberculous patients' own red cells instead of sheep red cells for performing the hemagglutination reaction. It has been independently observed by Fisher and Keogh in studies on the application of the hemagglutination test for tuberculosis in cattle (7); and what appears to be the same phenomenon has recently been observed in serologic studies on trypanosomiasis (8).

\section{METHODS}

\section{A. Technique for performing the hemagglutination test with the use of sensitized homologous red cells}

\section{Collettion of blood to be tested}

About $5 \mathrm{ml}$. of blood were collected in a syringe and transferred to a $25 \mathrm{ml}$. Erlenmeyer flask containing six to 10 small glass beads. The flask was shaken in a rotary fashion to effect defibrination of the blood. The liquid portion of the defibrinated blood containing serum and suspended cells was poured into a Wassermann tube (about $11 \mathrm{~mm}$. outside diameter and $100 \mathrm{~mm}$. long) and centrifuged. One ml. of supernatant serum was removed to another tube and treated as indicated in III. The sediment of red cells in serum served as the source of red cells to be sensitized.

\section{Preparation of sensitized red cells}

The sediment of red cells and serum prepared as described in I was diluted with several volumes of phosphate-buffered saline $(0.01 \mathrm{M}$ dibasic sodium phosphate solution containing 0.8 per cent of sodium chloride and adjusted to $\mathrm{pH} 7.0$ with $1 \mathrm{~N} \mathrm{HCl}$ ) and centrifuged; the supernate was discarded; and the red cells were washed three times with several volumes of phosphate-buffered saline.

One aliquot of $0.05 \mathrm{ml}$. of these packed, washed red cells was added to $2.4 \mathrm{ml}$. of a 1:12 dilution of a special "Tuberculin" preparation 1 in phosphate-buffered saline. This mixture was incubated at $37^{\circ} \mathrm{C}$. and agitated every 15 minutes for two hours. It was then centrifuged; the supernate was discarded; and the sedimented red cells were washed three times by resuspending in several volumes of phosphate-buffered saline and centrifuging. Finally, the washed, sensitized red cells were resuspended in $10 \mathrm{ml}$. of phosphate-buffered saline; this constituted the 0.5 per cent suspension of "sensitized red cells."

\section{Performance of the test}

Twofold serial dilutions of the serum prepared as described in I were made in phosphate-buffered saline, from $1: 4$ to $1: 128$. To each tube was added an equal volume of the 0.5 per cent suspension of sensitized red cells.

Two control tubes were included in each test: 1 ) equal volumes of $1: 4$ dilution of the patient's serum and "unsensitized red cells" suspension, 2) equal volumes of phosphate-buffered saline and "sensitized red cells" suspension.

All tubes were incubated at $37^{\circ} \mathrm{C}$. for two hours; after complete settling of the red cells had occurred, the rack of tubes was shaken vigorously and allowed to stand undisturbed at room temperature overnight.

The results were read and recorded in terms of hemagglutination or hemolysis.

\section{B. Technique for performing the hemagglutination test with the use of sensitized sheep red cells}

\section{Collection and preparation of serum to be tested}

Serum was collected as for a Wassermann test; about $1.0 \mathrm{ml}$. of serum was sufficient. It could be stored in the cold or, preferably, in a deep freeze unit for many months. It was inactivated just before use in the test by heating at $56^{\circ} \mathrm{C}$. for 20 to 30 minutes, and diluted with three volumes of phosphate-buffered saline.

\footnotetext{
1 An old tuberculin preparation from the cultures of three different human strains of tubercle bacillus; it possessed a tuberculin skin test activity about four times the International Standard (see Scott and Smith [4]). It was kindly supplied for our use by Doctors Joyner and Piersma of the Lederle Laboratories, Pearl River, New York.
} 


\section{Preparation of washed, packed sheep red blood cells}

Sheep's blood was collected aseptically in 1.2 volumes of sterile, modified Alsever's solution:

$\begin{array}{lc}\text { Glucose } & 2.05 \mathrm{gm} . \\ \text { Sodium citrate } & 0.8 \\ \text { Sodium chloride } & 0.42 \\ \text { Distilled water } & 100 \mathrm{ml} .\end{array}$

The $\mathrm{pH}$ was adjusted to 6.1 with 10 per cent citric acid solution. It was autoclaved at 10 pounds for 15 minutes.

Alsever's-sheep's blood mixture was stored at $4^{\circ} \mathrm{C}$.; it was not used until at least three days after collection. If kept sterile, the mixture remained suitable as a source of sheep red cells for at least three months.

When sheep cells were required, an appropriate aliquot of this mixture was removed and centrifuged; the red cells were washed three times with at least five volumes of phosphate-buffered saline.

\section{Sensitization of sheep red cells}

Lederle's special "Tuberculin" preparation was diluted with 11 volumes of phosphate-buffered saline. To 48 volumes of this diluted antigen, one volume of packed, washed sheep red cells was added. The mixture was incubated at $37^{\circ} \mathrm{C}$. and agitated every 15 minutes for two hours in order to prevent settling of the red cells during this period of sensitization and to assure uniform sensitization of the cells. This mixture was centrifuged, and the supernate discarded; the sedimented red cells were washed three times by resuspending in large volumes of phosphate-buffered saline and centrifuging. Finally, the washed, sensitized sheep cells were resuspended in 200 volumes of phosphate-buffered saline; this constituted the 0.5 per cent suspension of "sensitized sheep red cells." It was stored at $4^{\circ} \mathrm{C}$. and used within three days. The preparation was discarded as soon as it showed signs of hemolysis.

\section{Absorption of test serum with untreated sheep red cells}

Serum antibodies unrelated to tuberculous infection may agglutinate unsensitized as well as sensitized sheep red cells; these antibodies must be removed from the serum before performing the test.

To $4 \mathrm{ml}$. of the 1:4 dilution of heated serum placed in a narrow tube was added $0.2 \mathrm{ml}$. of packed, washed, untreated sheep cells. The cells were well suspended and allowed to stand at room temperature for 10 minutes and then centrifuged at high speed $(2,000$ to 2,500 r.p.m.) for 10 minutes; without removal of the supernate, another $0.2 \mathrm{ml}$. of packed, washed, untreated sheep cells was added and mixed with the supernate with as little disturbance of the first $0.2 \mathrm{ml}$. of packed red cells as possible. This suspension was allowed to stand at room temperature for 10 minutes and centrifuged at high speed as before. The supernate was removed and used as 1:4 dilution of "absorbed test serum."

\section{Preparation of suspension of unsensitised sheep red cells}

To 200 volumes of phosphate-buffered saline, one volume of packed, washed, untreated sheep red cells was added; this 0.5 per cent suspension served as "unsensitized sheep red cells control" in the test.

\section{Performance of the test}

Five-tenths ml. amounts of twofold serial dilutions of the "absorbed test serum" were made in phosphatebuffered saline, from $1: 4$ to $1: 128$. Added to each tube was an equal volume of the 0.5 per cent suspension of sensitized sheep cells. Two control tubes were included in the test: 1) equal volumes of $1: 4$ dilution of "absorbed test serum" and "unsensitized sheep red cells control" suspension, 2) equal volumes of phosphate-buffered saline and "sensitized sheep red cells" suspension.

All tubes were incubated at $37^{\circ} \mathrm{C}$. for two hours; after complete settling of the red cells had occurred, the rack of tubes was shaken vigorously and then allowed to stand undisturbed at room temperature overnight.

The results were recorded in terms of agglutination,

In each test series was included a known positive standard serum in the form of a pool of rabbit antisera against a living attenuated strain of tubercle bacilli prepared as described by Middlebrook and Dubos (1).

\section{Technique for performing the "hemolytic modification" of the hemagglutination test with the use of sheep red cells and guinea pig complement}

The materials and methods used in this modification of the hemagglutination reaction were precisely the same as those used in the hemagglutination reaction described in B above, except that to each tube of that test was added an excess of "absorbed complement." This was prepared in the following manner:

One volume of packed, washed, unsensitized sheep cells (from the same batch as was used in the hemagglutination test) was mixed with 15 volumes of $1: 3$ dilution of pooled, fresh guinea pig serum ${ }^{2}$ in phosphate-buffered saline. The mixture was allowed to stand at about $4^{\circ} \mathrm{C}$. for 10 minutes; it was then centrifuged at high speed $(2,000$ to 3,000 r.p.m.) for 10 minutes. Without removal of the supernate, another equal volume of packed, washed, unsensitized sheep cells was added and suspended in the supernate, with as little disturbance as possible of the sedimented first aliquot of packed sheep cells. This was allowed to stand another 10 minutes at $4^{\circ} \mathrm{C}$., then centrifuged at high speed. The supernate thus obtained was used as "absorbed complement." Little or no hemolysis should occur during this absorption. It should be pointed out that elevation of temperature of the mixture during absorption above $25^{\circ} \mathrm{C}$. may result in undesirable hemolysis and loss of complement activity.

2 A product sold as "Dehydrated Complement" by the Texas Biological Laboratories, P. O. Box 722, Fort Worth, Texas, has been found satisfactory; this lyophilized guinea pig serum was restored to its original volume by the addition of sterile distilled water. 
To each tube in the hemagglutination test, after it had been completely set up, $1 / 20$ volume of this "absorbed complement" was added. (For example, if each tube of the test contained $1.0 \mathrm{ml}$. total volume of reagents, then approximately $0.05 \mathrm{ml}$, , or one drop from the tip of a 1.0 ml. pipette, of the "absorbed complement" was added to each tube.)

The racks of tubes constituting the test were incubated at $37^{\circ} \mathrm{C}$. for one hour; each rack was shaken vigorously at 15 to 20 minute intervals. The test was read for hemolysis after allowing the red cells to settle at room temperature onto the bottom of the tubes.

The presence of hemolysis indicated that antibody was present in the test serum for the component(s) of tubercle bacillus which had been adsorbed onto the red cells. The presence of hemolysis of significant extent in the control tubes would invalidate the test and indicate that either 1) the guinea pig serum ("complement") was incompletely absorbed with unsensitized red cells, or 2) the guinea pig serum ("complement") contained antibodies for the material adsorbed onto the sensitized red cells, or 3) both 1) and 2). Neither of these "false reactions" has, as yet, been observed with the methods described here.

"Absorbed complement" should be used soon after it is prepared or stored at refrigerator temperature and used within three or four hours.

A completely absorbed guinea pig serum which still had high complement activity was found to be an essential reagent for obtaining reliable results in this test. It has been shown in additional experiments that the 1:60 final dilution of "absorbed complement" employed in this test should be at least threefold the amount necessary to cause in one hour at $37^{\circ} \mathrm{C}$. complete hemolysis of a 0.25 per cent (final concentration) suspension of sheep red cells sensitized with an excess of sheep cell hemolysin (anti-sheep-red-cell rabbit serum). The hemolytic titer of the standard positive serum which was included in each test series (see VI under B in Methods) was determined with a preparation of "absorbed complement" which had known high complement activity. The hemolytic titer of the standard positive serum in each subsequent test series would allow, by comparison, a roughly quan- titative estimation of the complement activity of the particular "absorbed complement" preparations used. ${ }^{3}$ In point of fact, the relatively constant hemolytic titer of the standard serum in many test series gave assurance that "absorbed complement" prepared as described here had reproducibly high complement activity.

\section{RESULTS}

\section{Reactions between sera and sensitized homologous erythrocytes}

It was found possible to sensitize the washed homologous red cells of tuberculous patients with aqueous extracts of tubercle bacilli (strain H37Rv) or with certain preparations of old tuberculin (such as Lederle's special tuberculin) so that the red cells would be agglutinated by the patients' sera. In low dilutions of such sera, when they were employed fresh and unheated, hemolysis was often observed; this occurred most rapidly during the first hour of incubation. Table I shows results typical of those obtained with several sera of patients with active tuberculosis.

After heating of such positive sera at $56^{\circ} \mathrm{C}$. for 30 minutes, agglutination of the sensitized red cells took place to the same titer as with the unheated serum, but no hemolysis occurred in the low dilutions of serum. These results suggested that the complement activity of fresh, unheated serum might be involved in the lysis of the sensitized red cells by antibody in the serum.

\footnotetext{
${ }^{3}$ More precise quantitative methods are applicable in this test, but for that purpose 50 per cent hemolysis endpoints and more rigorous control of several variables would be necessary; these problems are beyond the scope of the present paper.
}

TABLE I

Agglutination and lysis of sensitized red cells by fresh unheated, homologous serum of a tuberculous patient

\begin{tabular}{|c|c|c|c|c|c|c|c|c|c|}
\hline & & \multicolumn{8}{|c|}{ Dilutions of unheated serum* } \\
\hline & & $1: 4$ & $1: 8$ & $1: 16$ & $1: 32$ & $1: 64$ & $1: 128$ & $1: 256$ & Saline \\
\hline \multirow{2}{*}{$\begin{array}{l}\text { Sensitized red } \\
\text { cells }\end{array}$} & Agglutination & (Lysis) & (Lysis) & +++ & +++ & +++ & ++ & \pm & $\mathbf{0}$ \\
\hline & Lysis & +++ & ++ & \pm & 0 & 0 & 0 & 0 & 0 \\
\hline \multirow{2}{*}{$\begin{array}{l}\text { Unsensitized red } \\
\text { cells }\end{array}$} & Agglutination & 0 & \multicolumn{6}{|c|}{ Not done } & 0 \\
\hline & Lysis & 0 & \multicolumn{6}{|c|}{ Not done } & 0 \\
\hline
\end{tabular}

* All dilutions of serum recorded in this paper refer to the dilution of the serum before it was mixed with an equal volume of red cell suspension. Thus, a recorded dilution of $1: 4$ is equivalent to a final dilution of $1: 8$. 
TABLE II

Results of hemagglutination $(B)^{*}$ and hemolytic modification $(C) \dagger$ tests on the sera of seven tuberculous patients

\begin{tabular}{|c|c|c|c|c|c|c|c|c|c|c|}
\hline \multirow{2}{*}{ Sera tested } & \multirow{2}{*}{ Type of test } & \multicolumn{9}{|c|}{ Dilutions of heated, sheep cell-absorbed sera } \\
\hline & & $1: 4$ & $1: 8$ & $1: 16$ & $1: 32$ & $1: 64$ & $1: 128$ & $1: 256$ & $1: 512$ & $1: 1024$ \\
\hline 26 & $\begin{array}{l}\text { B } \\
\text { C }\end{array}$ & $0^{++}$ & $\begin{array}{l} \pm \\
0\end{array}$ & $\begin{array}{l}0 \\
0\end{array}$ & $\begin{array}{l}0 \\
0\end{array}$ & $\begin{array}{l}0 \\
0\end{array}$ & $\begin{array}{l}0 \\
0\end{array}$ & $\begin{array}{l}0 \\
0\end{array}$ & $\begin{array}{l}0 \\
0\end{array}$ & $\begin{array}{l}0 \\
0\end{array}$ \\
\hline 27 & $\begin{array}{l}\mathrm{B} \\
\mathrm{C}\end{array}$ & $\begin{array}{l}++++ \\
+t+t\end{array}$ & $\begin{array}{l}+++t \\
++t+\end{array}$ & $\begin{array}{l}++++ \\
++++\end{array}$ & $\begin{array}{l}++++ \\
++t+\end{array}$ & $\begin{array}{l}++t \\
++t+\end{array}$ & $\begin{array}{l}+t \\
+t+t\end{array}$ & $\frac{t}{+}+t$ & $\begin{array}{l} \pm \\
+\end{array}$ & $\begin{array}{l}0 \\
0\end{array}$ \\
\hline 29 & $\stackrel{\text { B }}{\mathbf{C}}$ & $\begin{array}{l}++t+ \\
+t+t\end{array}$ & $\begin{array}{l}++t \\
+t+t\end{array}$ & $\stackrel{+}{+t+t}$ & $+t+t$ & $+t+t$ & $\begin{array}{l}0 \\
++++\end{array}$ & $\begin{array}{l}0 \\
++++\end{array}$ & $\stackrel{0}{+}++$ & $\begin{array}{l}0 \\
++\end{array}$ \\
\hline 36 & $\stackrel{\mathrm{B}}{\mathrm{C}}$ & $\begin{array}{l}++t \\
++t\end{array}$ & $\begin{array}{l}++t \\
++t\end{array}$ & $\begin{array}{l}++t \\
++t\end{array}$ & $\begin{array}{l}+t+ \\
+\end{array}$ & $0^{++}+$ & $0^{++}$ & \pm & $\begin{array}{l}0 \\
0\end{array}$ & $\begin{array}{l}0 \\
0\end{array}$ \\
\hline 38 & $\stackrel{\mathrm{B}}{\mathrm{C}}$ & $\begin{array}{l}++ \\
+t+\end{array}$ & + & $0^{+}$ & \pm & $\begin{array}{l}0 \\
0\end{array}$ & $\begin{array}{l}0 \\
0\end{array}$ & $\begin{array}{l}0 \\
0\end{array}$ & $\begin{array}{l}0 \\
0\end{array}$ & $\begin{array}{l}0 \\
0\end{array}$ \\
\hline 40 & $\begin{array}{l}\mathrm{B} \\
\mathrm{C}\end{array}$ & $0^{++++}$ & $\begin{array}{l}++++ \\
\pm\end{array}$ & $\begin{array}{l}+t+t \\
\pm\end{array}$ & $\begin{array}{l}+++t \\
\pm\end{array}$ & $\begin{array}{l}++t \\
\pm\end{array}$ & ${ }_{0}^{+t+}$ & $0^{++}$ & $0^{+}$ & $\begin{array}{l}0 \\
0\end{array}$ \\
\hline 41 & $\begin{array}{l}\mathrm{B} \\
\mathrm{C}\end{array}$ & $\begin{array}{l}++++ \\
+++t\end{array}$ & $\begin{array}{l}++++ \\
+++t\end{array}$ & $\begin{array}{l}+++t \\
++t+\end{array}$ & $\begin{array}{l}++t \\
+t+t\end{array}$ & $\begin{array}{l}+t \\
t+t\end{array}$ & + & $\begin{array}{l}0 \\
0\end{array}$ & $\begin{array}{l}0 \\
0\end{array}$ & $\begin{array}{l}0 \\
0\end{array}$ \\
\hline $\begin{array}{l}\text { Standard } \\
\text { rabbit } \\
\text { antiserum }\end{array}$ & $\stackrel{\mathrm{B}}{\mathrm{C}}$ & $\begin{array}{l}1: 128 \\
++t+ \\
++t+\end{array}$ & $\begin{array}{l}1: 256 \\
+t+t \\
+t+t\end{array}$ & $\begin{array}{l}1: 512 \\
t+t \\
t+t+\end{array}$ & $\begin{array}{l}1: 1,024 \\
+t \\
+t+t\end{array}$ & $\begin{array}{l}1: 2,048 \\
+ \\
+++t\end{array}$ & $\begin{array}{l}1: 4,096 \\
0 \\
t+t+\end{array}$ & $\begin{array}{l}1: 8,192 \\
0 \\
+++\end{array}$ & $\begin{array}{l}1: 16,384 \\
0 \\
0\end{array}$ & \\
\hline
\end{tabular}

Note concerning controls: All the above sera were tested in a dilution of $1: 4$ with unsensitized sheep cells in both tests and neither hemagglutination nor hemolysis occurred, and the sensitized sheep cells in saline were unaffected by the "absorbed complement."

* Testing done as described under B in Methods.

$t$ Testing done as described under $C$ in Methods.

Reactions between sensitized sheep red cells and the sera of tuberculous individuals with and without added "absorbed complement"

When a constant amount of fresh or lyophilized guinea pig serum, absorbed with sheep cells, was added, as described earlier in this paper, to each tube in the hemagglutination test, hemolysis was often observed instead of hemagglutination, provided the serum tested was from a tuberculous animal, a rabbit recently infected with living attenuated tubercle bacilli, or a human being with active tuberculosis. Table II illustrates the results obtained with seven representative sera and the standard rabbit antiserum.

The results shown in Table II reveal that there is no obvious relation between the hemagglutination titer of a positive serum and its hemolytic titer in the hemolytic modification of the test. Serum 40 , which shows such a striking difference in hemagglutination and hemolytic titers, was studied for possible high anticomplementary activity and was shown to have no significant anti- complementary activity. Therefore, the failure of this serum to cause more marked hemolysis may be attributed to differences in the antigen-antibody reactions involved in agglutination and in lysis of the sensitized red cells. Indeed, it was shown in additional experiments that a mixture of equal volumes of $1: 128$ dilution of serum 40 (a dilution which causes definite agglutination of the sensitized sheep cells [see Table II]) and various dilutions of the tuberculin used for sensitization of the sheep red cells failed to fix complement in a complement fixation test performed by the classical technique. Thus, the dominant antigen-antibody reaction which is involved in hemagglutination by this serum appears to be one which does not fix complement. On the other hand, a mixture of equal volumes of $1: 512$ dilution of the standard serum (which causes both hemagglutination and, in the presence of complement, hemolysis of sensitized red cells [see Table II]) and certain dilutions of the same tuberculin did fix a small amount of complement.

These experiments did not show whether the 
differences between sera with respect to hemagglutination and hemolysis were due to their content of different antibodies against different antigens adsorbed onto the red cells or to different types of antibody directed against only one antigen. They did indicate, however, that the hemagglutination test can detect antibody which will not fix complement when that antibody combines with the corresponding antigen of the tubercle bacillus.

\section{Further studies on the sera of tuberculous individuals}

In addition to the seven sera already described, 20 additional sera of tuberculous patients were studied in the hemagglutination test and in the hemolytic modification thereof. Of these 20,18 were positive in $1: 16$ (or above) dilution of serum in the former test and the same sera were positive in $1: 8$ (or above) dilution of serum in the hemolytic modification. Thus, in a total of 27 tuberculous patients, 24 were positive in both tests and three were negative in both tests.

\section{Studies of sera from non-tuberculous individuals}

The sera of 10 non-tuberculous individuals, six of whom were ill with diseases causing markedly elevated serum globulins (multiple myeloma, hepatic cirrhosis and disseminated lupus erythematosus), were negative at $1: 16$ in the hemagglutination test and negative at $1: 8$ in the hemolytic modification test.

\section{DISCUSSION}

The observations described in this paper establish that erythrocytes onto which a specific antigen has been adsorbed can be lysed by complement and specific antibody for the adsorbed antigen. This is a novel serologic reaction, which, on further analysis, may provide more insight into the mechanisms of serologic hemolysis. It is possible that this phenomenon is related, at least in principle, to the leucocytolytic effect of a combination of tuberculin, a component of the euglobulin fraction of tuberculous sera and complement, as described by Favour and his associates $(9,10)$.

It is apparently unrelated to the recently described lysis of red cells by viruses which can occur in the absence of complement and is inhibited by specific antibody against a component of the virus particle $(11,12)$.
The preliminary studies reported here show that the hemagglutinative and the hemolytic properties of the sera of tuberculous patients show no necessary correlation with each other, except in a qualitative way. This may be interpreted as being due to qualitative differences in the antibodies involved in the two reactions with certain sera. The antibodies could be different either because they are directed against distinctly different antigens adsorbed onto the red cells or, because, directed against the same antigen, they nevertheless differ in "type," one type being able to agglutinate the treated red cells but not able to sensitize them to hemolysis in the presence of complement, another type being able to do the opposite. A third type, capable of manifesting both activities, may be present, of course. The results of the complement fixation tests with the soluble antigens and certain selected sera confirm the hypothesis that different antibodies may be responsible for the lack of necessary correlation in the two serologic reactions. It is possible, in any case, that investigation of the hemolytic modification of the hemagglutination test for tuberculosis will yield additional useful information concerning the relationship between tuberculous disease and humoral antibodies against antigenic components of tubercle bacilli.

Because of the limited number of sera examined, no conclusions can be drawn from the data reported here concerning the limits of usefulness of these tests for the diagnosis of tuberculosis and other mycobacterial diseases.

\section{SUMMARY AND CONCLUSIONS}

1. Human erythrocytes treated with extracts or products of the culture filtrates of tubercle bacilli can be used to detect in homologous human serum antibodies against specific components of tubercle bacilli.

2. A hemolytic modification of the hemagglutination test for antibodies against tubercle bacillus antigens has been described.

3. Comparative studies of the sera of tuberculous patients have shown that the hemagglutination test and its hemolytic modification do not necessarily measure the same serologic properties; this is interpreted as evidence that these tests do not necessarily measure the same antibodies. 


\section{ACKNOWLEDGMENT}

Sera used in this study were generously supplied by Dr. Sidney Rothbard of Montefiore Hospital, Dr. Henry G. Kunkel of the Hospital of The Rockefeller Institute, and Drs. Ralph Tompsett and Charles Le Maitre of the New York Hospital.

\section{BIBLIOGRAPHY}

1. Middlebrook, G., and Dubos, R. J., Specific serum agglutination of erythrocytes sensitized with extracts of tubercle bacilli. J. Exper. Med., 1948, 88, 521.

2. Gernez-Rieux, C., and Tacquet, A., Sur une réaction spécifique d'agglutination d'hématies sensibilisées, et sur son application au diagnostic de la tuberculose humaine. Bull. Acad. nat. méd., 1949, 133, 556.

3. Sohier, R., Réaction d'hémagglutination type Dubos Middlebrook réalisée avec une tuberculine purifiée résultats obtenus. Ann. Inst. Pasteur, 1950, 78, 283.

4. Scott, N. B., and Smith, D. T., A simple modification of the Middlebrook and Dubos hemagglutination test for serum antibodies to products of tubercle bacilli. J. Lab. \& Clin. Med., 1950, 35, 303.

5. Gernez-Rieux, C., and Tacquet, A., Réactions d'hémagglutination pratiquées comparativement avec l'antigène type Middlebrook et Dubos et avec la tuberculine précipitée. Ann. Inst. Pasteur, 1950, 78, 550.

6. Rothbard, S., Dooneief, A. S., and Hite, K. E., Practical application of a hemagglutination reaction in tuberculosis. Proc. Soc. Exper. Biol. \& Med., 1950, 74, 72.

7. Fisher, S., and Keogh, E. V., Lysis by complement of erythrocytes which have adsorbed a bacterial component and its antibody. Nature, 1950, 165, 248.

8. Muniz, J., Comportamento de hemátias sensibilizadas com a fração polisacarídeo do Schizotrypanum cruzi quando em presença de soros específicos. "Hemólise condicionada," um caso particular dentro das reações de imunidade. Hospital, Rio de Janeiro, 1950, 37, 199.

9. Favour, C. B., Lytic effect of bacterial products on lymphocytes of tuberculous animals. Proc. Soc. Exper. Biol. \& Med., 1947, 65, 269.

10. Favour, C. B., Leucocytic blockade of in vitro tuberculin cytolysis. Proc. Soc. Exper. Biol. \& Med., 1949, 70, 369.

11. Morgan, H. R., Enders, J. F., and Wagley, P. F., A hemolysin associated with the mumps virus. J. Exper. Med., 1948, 88, 503.

12. Kilham, L., A Newcastle disease virus (NDV) hemolysin. Proc. Soc. Exper. Biol. \& Med., 1949, 71, 63. 